\title{
The Function of the Superhero at the Present Time
}

\author{
Sean Carney
}

\begin{abstract}
History is no longer an enigmatic flux to which men and things are subjected. It is no longer a thing to be explained by the intervention of transcendental powers or made meaningful by reference to transcendental values. History is, on the one hand, the product (albeit the unconscious one) of man's own activity, on the other hand it is the succession of those processes in which the forms taken by this activity and the relations of man to himself (to nature, to other men) are overthrown. [...] And the nature of history is precisely that every definition degenerates into an illusion: history is the history of the unceasing overthrow of the objective forms that shape the life of man. [...] From this standpoint alone does history really become a history of mankind. For it contains nothing that does not lead back ultimately to men and to the relations between men. (Lukács 185-86)
\end{abstract}

If we accept the popular assumption that all superhero comics today live in the shadow of two towering monoliths that changed the face of the superhero, namely Alan Moore and Dave Gibbons' Watchmen (1986) and Frank Miller's The Dark Knight Returns (1986), then we may suggest a general organizing framework in which to situate an investigation into the current condition of the superhero. For the question which Watchmen and The Dark Knight Returns seem to have forced out into the open is: what is the social function of the superhero? This question is in fact double-voiced: it describes both the function of the superhero qua character

Sean Carney is Assistant Professor of Drama and Theatre in the Department of English at McGill University, Montreal. His work has appeared in Theatre Journal, Modern Drama. The Journal of Dramatic Theory and Criticism and Theatre Survey. His book Brecht and Critical Theory: Dialectics and Contemporary Aesthetics was published by Routledge in 2005. 
in a fictional world, and also the social function of the superhero, its social symbolism, within the reader's world. The answer inaugurated by both those books is a suitably double-voiced reply: the representation of fictional worlds in which superheroes are no longer welcome, and thus where their social function cannot be taken for granted. This becomes a reflection upon the ideological function of superhero comics. Both books offer situations where superheroes are forced to justify themselves to their societies, and this justification (or lack thereof) is simultaneously an argument for (or against) the social function of superheroes as ideological constructions in the reader's world. However much the problem of the social function of the superhero may have been a latent question in earlier moments (we could argue, for example, that the Silver Age, with its wry self-reflexivity and its revisionist re-situating of the superhero within more realistic contexts and problems, is also asking the question of the social function of the superhero), it was with Watchmen and The Dark Knight Returns that the question was forced, given overt expression in an artistic formulation suitably impressive as to make a lasting impact. The result is an irresolvable anxiety of influence for contemporary superhero comics.

By placing superheroes in more "realistic" settings, Frank Miller and Alan Moore have essentially inserted the superhero within social and political contexts. In this paper, I will examine how the anxiety provoked by Watchmen and The Dark Knight Returns forces subsequent superhero narratives to contend with themes that are inherently historical and political. In my approach, I differ from one of the most recent critical assessments of superhero comics, which reads them as refusals of Moore and Miller's "realistic" politicization of the superhero. The anxiety of influence in contemporary superhero comics has been thoroughly investigated in Geoff Klock's insightful and groundbreaking How to Read Superhero Comics and Why (2002), but the rigorous formalism of Klock's analysis, and the constant prioritizing of his thesis that superhero comics today are only about other superhero comics, without reference to social or political contexts, leads Klock into a series of depoliticizing gestures in his readings, which originate in his refusal of myth criticism as a valid means of enquiry. His reading of the conclusion of The Dark Knight Returns, for example, is anxious about its own refusal of the political implications of Miller's narrative (Klock 49). The strength of Klock's scholarship is precisely its sense of historical continuity, including its awareness of the historical periods of superhero comics and the historical revisionism implicit in superhero narratives. However Klock's history of superheroes is just that, a history of superheroes, while my analysis here argues that the history of superheroes must always be interpreted for its social symbolism, for superheroes as history.

My thesis here is that after 1986, the political function of the superhero has been subject to a transformation: from its origins as ideological myth, as popular symptom of closed, ideological consciousness, the superhero has been reinscribed with a hopeful ambivalence which transforms it into a symptom of history. This is to say that the superhero now is a symptom of humanity becoming historical, in a philosophical sense. Human beings are historical creatures because they have the ability to overreach themselves and be productive creators. This human overreaching is history itself. Yet the challenge of becoming historical, as described by Georg 
Lukács in the epigraph to this essay, is how to transform human consciousness into this productive overreaching, as a dialectical process. Humanity has yet to bridge the divide in consciousness between its achieved social forms and its ability to overreach and transform those achievements. Humans experience this historical process of overreaching themselves not as gain, but rather as alienation and loss. Humanity is alienated from its own human potential, from its ability to transform itself and the world. Humans experience history as a metaphysical process to which they are subjected, when in fact they are this process. As I shall argue, superheroes are an allegorization, a rendering conscious, of this process of humanity overreaching itself. The problem with traditional superheroes is that their narratives imply readers who will imaginatively abdicate responsibility for human actions to these heroes, in the same way that humans abdicate responsibility for their actions to something they call "history." When human actions become achieved forms that humans call history and that they elevate to a transhuman, metaphysical position, their own actions become alienated. Contemporary revisionist superhero narratives seek to return responsibility to humanity for its own deeds while also maintaining the importance of superheroes: they are necessary because they are figures for humanity's ability to overreach itself, but superheroes cannot be allowed to take over human responsibility from humans. Superheroes are thus allegorical figures for humanity's relationship to its own history; they are allegories for the human ability to create forms that are larger than humanity itself, and that humans then need to struggle with and repossess as their own agency.

Such a reading, however, first requires a return to the two towering monoliths so that the critic may sweep away some of the detritus that surrounds their interpretation. ${ }^{1}$ The popular reading of those books contains the assumption that their concerns were to make superheroes "more realistic." Thus these comics were attempts to rationalize and reify superheroes: the result was an alienation and an objectification of the form. Read as "realism," The Dark Knight Returns suggests that if Batman were real, he would be an outlaw and a vigilante, driven underground by a society unable to appreciate the importance of those heroes who work outside of conventional society, and who use violence and fear as a means of policing humanity. Understood literally, it is all too easy to read Miller's revisionism as a reactionary condemnation of American society's moral decay and of its inability to appreciate its exemplary figures due to the modern loss of values. The comic is then a condemnation of the modern, reified society. Miller's satire of modern attitudes includes broad caricatures of both the base selfishness of the modern conservative and the bleeding-heart tolerance of the American left-liberal. However, the heavyhandedness of these portrayals in the book, combined with Miller's simple, iconic style of illustration, caution the critic against literal interpretations. The level of satire here works to draw the reader's attention to what these "talking head" characters do in the book: they interpret Batman, arguing over his status as social symptom, or as some kind of social infection, about whether or not he provokes crime as much as he controls it (Miller, The Dark Knight Returns \#3/9). The point is not to answer such questions (which a literal reading of the book as a story about vigilantism would attempt to do), but rather to grasp the significance of the ques- 
tioning. The Dark Knight Returns is not a book attempting primarily to explain what superheroes are for, or what their social significance is. Instead such thinking is the problem in the book. The Dark Knight Returns resists answers to the meaning of the Batman (what his function is) and in so doing focusses upon the activity of meaning-making itself. Batman's nemesis in the story is Superman, and the conflict between them falls on the social function Superman has adopted. In an America where superheroes have been outlawed, Superman has continued to function by being indoctrinated as a secret weapon for the American military. This merely highlights how Superman has traditionally been associated with a conservative American ideology. Superman has always functioned as a flag, as a myth. Or rather, he almost immediately became this functionary. In his origins, however, Miller points out that Superman was something else: "Go back to the origins of Superman, before World War II. He was dragging generals to the front of battles. He was fighting corrupt landlords. He was not the symbol of the status quo he's since become" (Miller, "Batman and the Twilight of the Idols" 39). For Miller, superheroes emerged from an anti-establishment impulse born in the spirit of the New Deal, rather than beginning as icons for conservative "status quo" thinking.

Within the terms of Miller's narrative, this is exactly the problem with superheroes: they function as conservative myths which solve, in an imaginary manner, humanity's real social problems. Such imaginary solutions are false and therefore resolve nothing for the human race, merely exacerbating situations. Superman does this in the narrative by secretly intervening in the "Corto-Maltese Crisis," a military conflict between America and the U.S.S.R., involving U.S. support for a military dictator (\#3/9). When the Soviets are defeated, they respond by launching a single nuclear weapon, which Superman is forced to detonate in the African desert. Its consequences are devastating: the destruction of the African savannah and a global nuclear winter. The superhero as functionary, as problem-solver or "crimefighter," is a symptom of, and contributor to, humanity's abdication of responsibility for its own deeds, which leads to the possibility of the extinction of the human race. The significant shift, then, that The Dark Knight Returns performs, is the transformation of the superhero from an answer, into a question or a problem without solution. And this is how the most sober character in The Dark Knight Returns describes Batman. Batman is the contradiction between life and death that finds its most apparent expression in the social problem of war. Police Commissioner Gordon attempts to explain Batman to Gordon's successor with a story of how Franklin Roosevelt apparently knew Pearl Harbour was going to be attacked by the Japanese but deliberately did nothing, presumably so that the U.S.A. would enter the war and help bring about the historical conclusion which is, to the mind, the only possible, the necessary historical narrative: the defeat of the axis. Yet Gordon is troubled: "But a lot of innocent men died. But we won the war. It bounced back and forth in my head until I realized I couldn't judge it. It was too big" (\#2/40). This is Batman: an historical contradiction expressed in war, the necessity of murder and death in order for life to continue. For Gordon's replacement, Batman is a vigilante to be arrested, and this story does not explain Batman to her. For Gordon, Batman is a problem for the mind, "too big" to be understood, but he can be described 
allegorically with a narrative in which the American President allows American lives to be lost so that America will enter world history. For Gordon, Batman has never been a myth at all, but something so big that it frustrates human understanding. In other words, Batman is a contradiction, and moreover an historical one. Gordon is not able to rationalize the invasion of Pearl Harbour in such a manner. Roosevelt's solution is not acceptable to him, but neither can he reject it. He can only suffer the contradiction unhappily. This is the only position of truth a human can take in relation to the modern experience of history. It is necessarily traumatic, a position which inhabits the failure of sense and meaning, like the detonation of a nuclear weapon in the desert, which solves nothing, since life itself still suffers on a global scale.

As Batman demonstrates, this is the position of trauma itself, the failure of meaning which is the truth of history's contradiction. Batman's final showdown with Superman takes place in Crime Alley, where Batman's parents were murdered and where Batman's trauma became the unresolvable contradiction at the heart of him which drives him. From their deaths he learned that "the world only makes sense when you force it to" (\#4/40), which he contrasts sharply with the lesson Superman learned from his parents, a lesson in obedience to authority. Batman learned a lesson in trauma as necessity. Batman does not abandon sense or meaning; he instead avows that whatever order humans make from the world is only provisional and transitory, and a product of their own efforts, because beneath it is the bedrock trauma of history, as Commissioner Gordon describes it. In Miller's narrative, ideological closure, in the form of Superman, is demystified and in its place the reader is offered a perspective on history in the form of Batman. This necessitates that the conclusion of the narrative not be read literally, as the forming of an underground militia. The reader needs to attend to the ambiguity of the conclusion and acknowledge Miller's revisionism: over the course of the book Batman gives up his back-alley vigilantism, realizing that he has been misguided in his actions. I suggest that this is an abandonment of his function as a social myth. He fakes his own death, and starts training those whom he had once arrested. But what they are going to do is never entirely clear. Batman now sets himself "to bring sense to a world plagued by worse than thieves and murderers" (\#4/47), meaning, presumably, the American government which does not truly represent humanity's best interests. However, I think the reader needs to avoid reading beyond the end of the narrative here: Batman has achieved his goal at the end of the story; he has ceased to be a myth because he has ceased to serve a concrete social function. What he offers then is to be found precisely in the form of the comic itself: a narrative of the break from myth which gives the reader a perspective on history, as an unfinished narrative itself.

Superhero comics post-Watchmen and The Dark Knight Returns have responded to this awakening historical consciousness in two ways: on the one hand, through a misinterpretation of this revisionism as a simple rendering of superheroes "more realistically," which has resulted in a large body of inferior work exploring the "problems of the superhero in the real world." Alternately, and more significantly, the problem of history has come to be of primary importance in mainstream superhero comics of the 1990s. The most immediate example of this latter, produc- 
tive direction is Kurt Busiek and Alex Ross's Marvels (1994). Marvels takes revisionism a step further than The Dark Knight Returns by telling a story from the perspective of a middle-American everyman photographer named Phil Sheldon whose career is founded upon taking photos of superheroes. The illustrative style of Marvels is deceptive: the pleasure of the comic is initially based on Ross's realistic Norman Rockwell-esque paintings of the heroes of Marvel comics. The reader of Marvels might be forgiven for thinking this is another story about superheroes in "realistic" contexts due to the mimetic realism of the images. Yet I want to suggest that this is not a story about superheroes at all, but a deliberate allegory for shifts in American consciousness over four periods in twentieth-century history. As such, Marvels is a demonstration of how superheroes work as cultural myths, and, at times, as symptoms of history, which looms larger than mythic, national consciousness, threatening to cancel the closure of the ideological.

Book One of Marvels takes Pearl Harbour, the moment Commissioner Gordon describes in The Dark Knight Returns as Batman himself and as the unsolvable contradiction of history, and uses this same moment as the ground through which to analyze the emergence of the superhero. Busiek manages a deft balancing act of the literal and allegorical here. Book One begins in 1939 and, through the lens of Phil Sheldon, describes two narratives happening simultaneously. On the one hand, the beginning of the Second World War, and on the other, the appearance of the original Human Torch and the Sub-Mariner, Golden Age Marvel superheroes. Marvels asks the reader to see that these two phenomena, war and superhero, are the same thing. The story is an allegory, in a proper sense, for American consciousness and the American self-image as it is confronted by world-historical events happening beyond its borders, which it can only greet with fear and incomprehension. Phil Sheldon is a paradigmatic everyman-American. His thoughts about the superheroes are also the American thoughts about the nascent war: his experience is "a story of fear and awe. And a world cut loose from its moorings" (Busiek and Ross, Marvels \#1, n. pag.). The appearance of the Human Torch and the Sub-Mariner has a discomfiting effect on Phil Sheldon, making the island-world of New York seem smaller, because these Marvels are, as he puts it, "more than human." Whereas he had previously been eager to pursue a career as news photographer in Europe, Sheldon is now deeply afraid, but not of the coming war, rather of the superhumans. The effect on other Americans is identical: "Before they came. We were so big. So grand. We were Americans - Young. Strong. Vital! We were the ones who got things done. But we'd gotten smaller. I could see it in those same faces - faces that had once been so confident. So brash. We weren't the players anymore. We were spectators. We were waiting for something - without knowing what it was —." (\#1, n. pag.). Sheldon's problem in Book One is how to overcome that belittlement and sense of fear caused by figures that seem larger than American consciousness. Sheldon is resentful of something that seems to have thieved from Americans their place at the centre of the world. Of course, the "Marvels" as the heroes are called, are here being used as a description of history, as something larger than the human, in this case larger than the American human. The Marvels are simply that which, in their inexorable necessity, subject humans to their whims and decenter their confi- 
dence. The Churchillian metaphor Sheldon happens upon is that of a storm: "It was like a war - not just the battles. But the very fact of the marvels themselves. A war — or some freakish, violent storm" (\#1). Sheldon's frustration with the Marvels is that a storm or a war is larger than individuals and affords them no agency, offering them no restitution for the damage it causes.

The solution that immediately arrives is a heroic nationalist myth, which bridges the divide between Americans and world history: Captain America, a Marvel, no different from the others except that his costume is an American flag, and that he takes that flag into the war while America itself stays out of it. Yet in order for the conflict embodied by Sheldon to be resolved, he has to face the storm itself: when the Sub-Mariner brings a tidal wave against New York, Sheldon has his chance. This wave represents for him the end result of the brewing storm. Instead of hiding he bears witness to the fight between the Human Torch and the Sub-Mariner, and is blinded in one eye during the conflict. He awakens in a hospital bed to discover that Japan has attacked Pearl Harbour, and that America is at war. The allegory is transparent: the storm represented by the Marvels is the storm of world history, of necessity. Phil's loss of an eye is the Pearl Harbour attack. Whereas Miller represented the American encounter with necessity, Pearl Harbour, as an open contradiction, Busiek focusses instead on the social symbolism of the superhero as a mediating figure, who happily resolves the problem of history. Sheldon describes the world as changed, and America as having no choice but to change with it, and at the end of Book One, this is presented as emancipatory and romantic rather than as a suffering for the mind. The heroes have saved America, in as much as they have saved it from confronting history without a mythic mediator.

Having been offered, from the beginning of the narrative, a position outside of American consciousness looking in, the reader can appreciate the ingenious sleightof-hand that Busiek performs as he follows the allegory through to its conclusion. Book Two is concerned primarily with the Uncanny X-Men, who first appeared in comics in September 1963, but who function in Marvels as figures for those scapegoated by American paranoia and witchhunts during the 1950s. Phil Sheldon, patriotically inspired by Captain America and the new, "human" heroes like the Fantastic Four, pelts the mutant X-Men with bricks like everyone else. Phil Sheldon's only awareness that these two facets of public response are not separate but reciprocal comes to him in the darkroom: "I had to wonder: were the mutants the price we paid for the marvels? The negatives without which the pictures we wanted couldn't exist?" (\#2). Here Phil has an intimation of the necessarily unconscious, repressed content of consciousness. The X-Men here step into the place of history, which the Human Torch and the Sub-Mariner had previously occupied. The bounded national consciousness, without a relationship with the Other, must therefore produce an enemy to exclude. History remains disavowed, yet pressing necessity.

This is demonstrated in Book Three of Marvels, which uses a famous story from The Fantastic Four issues \# 48-50, concerning the coming of a world-devouring entity named Galactus, as an allegory for the Cuban Missile Crisis, and Book Four portrays the death of Gwen Stacy in The Amazing Spider-Man \#121-22 as an allegory for America's final loss of innocence during Viet Nam. Meanwhile the Kree- 
Skrull war from The Avengers \# 92-97, in which Phil's beloved Marvels are drawn to intervene in a conflict in another Galaxy between two alien races, serves as a standin for Viet Nam itself. This particular allegorization, more than any other in the book, indicates the xenophobia of American consciousness as figured through Phil: Viet Nam is only representable here as a far-distant conflict between alien races, and the Avengers intervene to save the human (American) race, but are not appreciated by Americans for risking their lives. Phil Sheldon himself becomes an aging, embittered crank, trying to hold on to the past, and resenting the growing American disillusionment with its heroes.

In an attempt to change public opinion about its myths, Sheldon decides that he will redeem Spiderman for the public. By now Marvels has reached the 1970s, and a growing public bitterness with the ideology offered by the government. Many readers of Marvels have taken Phil as the didactic spokesperson for the text as a whole. The major problem with agreeing with Phil Sheldon in his critical assessment of poor public reception of the heroes is that he is an unusual narrator: he always knows less than the reader. What is unconscious to him is conscious to the dedicated Marvel comics fan. Thus when Phil comments that Spiderman should beat up Peter Parker for Parker's slanderous photographs, the reader is afforded a laugh. The informed fan of Marvel comics knows they are the same person, and that Phil's crankiness is misguided. When two pages later Phil yells at people on the street, "You people! What do you need — the world to actually end?" (\#3), the real problem is with how Phil continues to see the world. He is angry at people for hating the heroes who save them. He wants them to look up to the Marvels. Phil wants the innocence which human history will not allow America to preserve. But Spiderman, of course, is both at once, both superhero and human, he is the secularized superhero, product of a changing world, a symptom of history subjecting humanity to its alienating necessities, and while Phil cannot see this, the reader can. Phil's obsession with the superheroes. his belief that they will always save humanity, is based in his desperate conclusion that their function is to save the innocent. Yet Spiderman fails to do this and Gwen Stacy dies, as the reader knows she did in the original comic book in 1973. As a result, Phil Sheldon gives up. He abandons his attempt to vindicate or explain the heroes. The world turns on, as he puts it: he cannot turn back the clock and recapture the way things were (or rather, as he imagined them to once be).

What, then, is the social function of the superhero, according to Marvels? In each book the Marvels seem to serve a double purpose: alternately functioning as symbols of American national consciousness and also as figures for the ongoing failure of that national self-image in the face of world-historical events. The social function of the superhero here is not to save the innocent. Rather the social function of the superhero is the allegorization of the ongoing, necessary loss of innocence. Marvels moves from a mythic vision of the hero as cultural symbol who protects readers from the loss of their ideological innocence, to a refashioning of the hero as loss of innocence in favour of the insight of historical consciousness. In other words, superheroes are now allegories for the ongoing, unending process of reification itself. History is a necessary experience of loss, to be constantly renewed. This secularization or reification is a dialectical process. It is the experi- 
ence of loss, the experience of necessity or inevitability, which is also a liberation from past forms which have shaped humans. Phil Sheldon has glimmers of this dialectical process, of the emancipatory power of history, early in Marvels, but he remains finally, curiously, unconscious. In the disjunction between what he would like the Marvels to be, and what they are, is the space for a readerly intervention. Their social function as Marvels is quite simply to challenge that which humans take as given, self-evident, and familiar to consciousness. Throughout the narrative the marvels constantly function to interfere with American national consciousness through the intrusion of that which is larger than consciousness. This manifests itself as the loss of innocence, the American fall from grace in the 1970s when Viet Nam forced America to confront its own national failure fully. The marvels must remain unconscious to Phil Sheldon. They are that which he is desperately angry to account for, explain, understand and redeem, but which remains tantalizingly out of reach. As marvels, their function is to not be understood.

The only real solution to Phil Sheldon's problem is a shift in consciousness itself. This shift is not available to Phil but Marvels offers it to the reader: a new way of interpreting history, which is just what Marvels does. This requires a new perspective on history, which also demands a new kind of perspective on totality. More than any other comics writer, Alan Moore imagines the contemporary conditions necessary for envisioning a perspective on totality that has liberating historical possibilities for the present. In his introduction to Mike Mignola's collection Hellboy: Wake the Devil (1997), Alan Moore illustrates the homology between the history of comics as a genre and the history of the human race in the twentieth century, and gives a perfect description of the ambivalent condition of postmodernity:

The history of comic-book culture, much like the history of any culture, is something between a treadmill and a conveyor belt: $[\ldots][\mathrm{N}]$ owhere do we have the opportunity to say, "We like it here. Let's stop." History isn't like that. History is movement, and if you're not riding with it then in all probability you're beneath its wheels.

Lately, however, there seems to be some new scent in the air: a sense of new and different possibilities; new ways for us to interact with History. [...]

In this new perspective, there would seem to be new opportunities for liberating both our culture and ourselves from Time's relentless treadmill. We may not be able to jump off, but we're no longer trapped so thoroughly in our own present moment, with the past a dead, unreachable expanse behind us. From our new and elevated point of view our History becomes a living landscape which our minds are still at liberty to visit, to draw sustenance and inspiration from. (Moore, "Introduction," v)

For Moore, the function of the classic superhero as art form becomes an implicit call towards such a postmodern historiographic vision, in which history is no longer a relentless treadmill ("an enigmatic flux" to which humanity is subjected, as Lukács 
puts it [185]), in fact it is no longer a temporal experience at all. History is an experience of space, Moore's "living landscape" which contains potential for new historical agency. History becomes present experience, and out of the productive combination of past and present an active, emancipatory vision emerges. The past must be viewed productively, not as an objective narrative that determines those in the present, but as a raw material from which to build a productive human future. Moore's philosophy of history is acted out in Judgment Day (1997).

Judgment Day begins in a manner so trite as to seem banal, apparently asking, yet again, the tired questions which derivative superhero comics have asked in the wake of Moore and Miller's work. A superhero is accused of the murder of one of his team-members, and the problem is: should he be subjected to a public trial like a normal human being? Moore's lack of interest in the question of "realism" in superhero comics emerges in the unusual denouement of the case. Tried by a tribunal of superheroes, the accused is acquitted when a strange narrative emerges about a magic book, created by Mercury, the mad god of language and laughter. Judgment Day is not in fact about the murder trial; it is about this book, which is the book of the human race, wherein are writ the stories of all humanity. It is human history as a book. When it is passed down to the realm of matter at the dawn of time, this book makes its way from hand to hand, possessed by a series of characters who are thinly-veiled counterfeits of famous heroes from myth and fiction (King Arthur, Tarzan, Solomon Kane, Professor Challenger, Conan). Whoever possesses the book has the ability to scratch out the existing story and write a new one, in effect rewriting their own future.

This is what happens when a young African-American teen from the ghetto named Marcus Langston happens upon the book in 1958. He reads his own story and finds that he is foretold to die at 19 robbing a liquor store. Marcus rewrites his story: he creates himself as a 1970s superhero. Here, Moore engages in a sublime survey of the increasing "realism" that transformed superhero comics in the silver age of the 1960s, the bronze age of the 1970s, and finally the dark or baroque age of the 1980s. In so doing, Judgment Day situates itself in the Renaissance age of the 1990s. The actual arrival of the African-American superhero in the 1970s was, of course, a movement towards realism in comics that was emancipatory and historically progressive, an attempt to reflect a changing society, a society which by changing was itself attempting to "rewrite" the so-called foretold end for AfricanAmerican lives. Thus that Marcus finds the book in 1958, just as the American Civil rights movement was about to explode into action, is no accident. American history itself, as it unfurled in the 1960s and 1970s, was just such a re-writing of the book of history, an assertion that the visible end for African-Americans needed to be changed and rewritten. Marcus does this for himself, but by the mid-1980s Marcus grows bored: "He decides to write a nastier, shadowier and more violent world for himself ... and for everyone else. Our entire reality changed and darkened. Gone was the naive wonder of the "forties, the exuberance of the "fifties and the nobility of the 'sixties. Working a dreadful reverse alchemy, Marcus Langston let our world slide from a Golden Age to a Silver Age, and finally to a Dark Age. Now, heroes motivated only by money or psychopathology stalked a paranoid, apocalyptic landscape of 
post-nuclear mutants and bazooka wielding cyborgs" (\#3, n. pag.). In this allegory for its own history, Judgment Day surveys the historical effect of reification on the superhero form, which culminated, ironically, in the "Watchmen-Dark Knight" effect: cynical, violent, amoral comics with neither charm, value, nor a sense of their own history informing them. This reification is most readily described as a fall from grace or loss of innocence, but with ambivalent possibilities within it. In Judgment Day, what began as an emancipatory rationalization, a reification of older narrative forms in a progressive attempt to create new, more human narratives, resulted in an abandonment of history altogether. The result is the postmodern condition, an apocalyptic cinemascape of post-human mutants and cyborgs. Yet it began as a progressive action: the creation of a more human world where an urban black youth was not pre-destined to die robbing a liquor store.

Thus for Moore, this fall from grace is not to be lamented nostalgically but employed productively, for the new perspective on history it makes possible. Judgment Day is a narrative not of disaster but of apocalyptic revelation and insight: here, it is insight about comic books themselves and their perspective on history. Like comic books themselves, human history is not a determined narrative, but a dialectical narrative, like the book of life which can always be rewritten. How, then, does Moore imagine comics can give readers the perspective on history that allows them to escape the vision of history as a treadmill (a mechanical determinist narrative) and see history instead as a totality, as a "living landscape which our minds are still at liberty to visit" (Moore, "Introduction," v)? The answer is found not at the level of content, but at the level of form. This is appropriate to the philosophical concerns of this essay, since, as Lukács argues, history is always the achieved forms taken by human activity (185-86). If humanity is the content, history is the form, and the dialectical intervention posits an attempted identity between the two. While Moore is the most prolific of contemporary comics writers, I want to focus upon the example of Moore's work which could be understood to be retro-pastiche in its most derogatory sense, Supreme (1996-2000), in order to unearth Moore's theory of history as embodied in superhero comics.

Supreme began as a rationalized copy of Superman, refigured as violent and inhuman. Moore took over the writing and revised the revision, transforming $\mathrm{Su}$ preme into a charming piece of escapism, reminiscent of an idealized Golden Age superhero. Yet Supreme is a contemporary hero with a Golden Age history, and this latter element manifests itself in the book through the mimicking of historical comic book styles and forms by Moore and artist Rick Veitch. When these retro-narratives are contrasted with Moore's contemporary Supreme narrative and its style of illustration, a stylistic dissonance is created. Initially, the contemporary illustration style is simply the overwrought, cold, technical veneer of most contemporary superhero illustration, dominated by an inhuman, pneumatic, generic, anatomical rendering of figures in hard lines and angles, bulging with grotesquely overdeveloped muscles, combined with technical, impersonal computer-coloring that blends with and shades the images. It is, in my opinion, superhero illustration at its absolute worst, affording nothing resembling enjoyment. This contemporary style is constantly interrupted by Rick Veitch's accomplished illustrations of a variety of older 
styles: EC Horror comics of the 1950s, DC comics heroes of the '40s, '50s, '60s and '70s, Jack Kirby's Marvel work from the 1960s, and even a parody of a famous Mad magazine superhero parody by Harvey Kurtzman and Wally Wood ("Supremelvin!!!"). Veitch's illustration style is warm, open and welcoming, filled with humour and caricature, while Bill Wray's coloring is deliberately flat, fourcolour work, sharply separated and muted in tones, representing a simple, unambiguous two-dimensionality. Todd Klein's lettering is similarly nostalgic in its evocation of past forms. Yet the effect of Supreme as a whole is that these incompatible styles, the old and the new, are forced to cohabit uncomfortably. There is an effect that needs to be described here, of an unhappy contradiction created for the reader in the dissonance between styles. If any single style may be understood to embody an ideology of form and thus function as an ideologeme, then I suggest that the content of the form of Veitch's nostalgic images evokes the traditional, ideological social function of the superhero, as collective symptom of innocent, closed consciousness, the all-too recognizably human superhero. Meanwhile the contemporary style evokes the reified, rationalized, "realistic" hero, which is itself no less ideological: the superhero as fascist, as remorseless, amoral vigilante, as essentially inhuman. As storyteller, however, Moore does not ask or allow the reader to choose between them. Instead, the effect of Supreme is to effectively force the reader to inhabit the contradiction between styles as an untenable reading position. It is, in other words, a generic discontinuity at the level of form which locates the reader in productive incoherence. Supreme presents both pleasure and discomfort, familiarity and alienation, and Supreme asks the reader not to choose between the two, but to instead find the productive pleasure to be found in alienation itself, as an ongoing process. I am suggesting here that Moore's work on Supreme is in fact the performance of the superhero comic as deliberate failure, but that Supreme turns the alienation between styles into the joy of aesthetic experience itself. This is a utopian glimpse of history in the contradiction of discontinuity, as that which emerges in the failure of the ideology of form.

Finally, the critic is left with the superhero today fulfilling an ambivalent, Janusfaced function, and the artist who reveals the two faces of the superhero most clearly is Warren Ellis. Today, the superhero is fully emancipated from its function as crime-fighter. In fact, practically the only place one can still see superheroes fulfilling this role is in motion pictures. This is an exaggeration meant to emphasize that comic books have largely abandoned this ideological function in their contents. In Planetary, drawn by John Cassaday, Ellis offers the function of the superhero as the maintenance of a sense of totality, but of totality as a strangeness for the human mind. The heroes of Planetary, while they have recognizably superhuman abilities, are not superheroes in any traditional sense. They do not "fight crime." Instead they are "archaeologists of the impossible," as the cover of the first issue announces. "We gather information on the hidden wonders of the world. Mystery archaeologists. There's a hundred years of fantastic events that Planetary intends to excavate. We're mapping the secret history of the twentieth century" (Planetary: All Over the World and Other Stories, "Preview Story" n. pag.) This function, exemplified by the heroes in the Planetary organization, is juxtaposed with 
the villains of the narrative, a barely-disguised rendition of The Fantastic Four transformed into Cold War American military despots who serve the opposite function to Planetary. The function of these "Four Voyagers" is to suppress and control the strange, to capture and use the strange for their owns ends. It is only by recognizing that the Four Voyagers are Ellis's vision of the effect of the Cold War on human history that the reader can grasp the political importance of the heroes of Planetary as a commentary on the social function of the superhero today.

In Planetary, strangeness erupts in the world due to the creation of a computer in 1945 by a group of globe-trotting adventurers whom Ellis bases on Doc Savage and his associates. The computer is a machine, "a theoretical snowflake" that actually creates other universes as theoretical models for solving the problem of history itself (Planetary: All Over the World\#1, n. pag.). The team of adventurers create the machine despite the risks it poses, risks based on the possibility that "the solved equation could rewrite the entire planet's reality, making its mathematical answer an objective truth." The machine's interpretation of reality might become reality. The computer is created anyway because "It could furnish us with a solved equation that constituted the perfect plan to end the war as soon as possible, with a minimum death, creating the best possible world society as a result." As in The Dark Knight Returns, the problem of history in the form of World War II, its traumatic contradiction and the attempt to resolve it, is the driving force of the narrative. However, the result of the machine is a multiplicity of universes, with a "reality bleed" between them: superhumans from a reality next door realize their universe is just a theoretical equation to be tested and rubbed out in the search for the perfect world, and they try to destroy Doc Brass's reality. Henceforth, every issue of Planetary sees its representatives investigating a strange locale and incident which seems to be the result of this theoretical snowflake, and in large part all that Planetary do is gather information on the strange, such as an Island near Japan full of dead creatures resembling Godzilla and his ilk (Planetary: All Over the World\#2). The monsters are there to "remind us of our greatness and horror," a Mishima-like fanatic explains, and certainly this seems to be the point of the story: the final image of issue two is of a winged monster flying overhead, followed by the look of pure joy this brings to the faces of the Planetary heroes.

Thus the function of Planetary is not so much to police the bleed between universes from which the strange erupts, as to bear witness to it and celebrate it. But at the same time, this simple activity of "archaeology" is portrayed as saving the world. The constant refrain of Planetary is that the "world" is strange, and that it should be kept that way. The only real conflict in the book arises from superheroes. It eventually emerges that the villainous "Four Voyagers" are themselves products of exposure to the theoretical snowflake in space during the race to reach the moon before the U.S.S.R. (Planetary: All Over the World \#6), and that these now superpowered Cold Warriors have since 1961 harvested and sequestered the strange phenomena that have erupted out of the bleed between universes. Planetary member Elijah Snow confronts one of the Four Voyagers: "I only know the barest part of what you do. I know that you've done more than your share of making the world mediocre. The things we've seen here alone: if I understand them 
right, then they alone could save millions of lives a year" (\#6). The Four Voyagers, created by the theoretical snowflake of the multiverse, are the secret history that Planetary seeks to unearth and bring to light. The Four Voyagers, a thinly-veiled version of Marvel's Fantastic Four, serve as a commentary by Ellis on the traditional, ideological function of the superhero. The Four Voyagers are cold-war history as it actually happened: history as the repression of possibility. What has been disavowed by cold war history is still present, as the disavowed itself, as the strange history Planetary seek to bring to light. The Four Voyagers have quite literally impoverished the world through their deeds, deeds which were precisely to make superheroes functional. In issue number ten, this ideological and literal functionalizing of the superhero is rendered with brutal clarity. Planetary learn that the Four Voyagers have for decades been tracking down and neutralizing powerful figures for the sole purpose of furthering military intelligence. The three figures who are cut down by the Four Voyagers are an alien infant wrapped in a red cape (Superman), an enlightened amazonian ambassador from a hidden all-female civilization (Wonder Woman), and an alien with a lantern-shaped piece of technology in his chest (Green Lantern). All three are destroyed by the Four Voyagers so that their technology can be sold to military interests, in other words, so that they can be rendered functional. What Ellis suggests here is that the silver-age superheroes of the Cold War, fighting crime and communists, destroyed the essential strangeness and wonder of Golden Age heroes. This revisionism is creatively false, suggesting that the functionalizing of the superhero happened after 1961, when in fact the Golden Age heroes served ideological ends as well (although we might keep in mind here Frank Miller's insight that Superman was originally an antiestablishment, people's hero, serving as a progressive wish-fulfillment rather than as a tool of the status quo).

Planetary arrive as heroes whose function is to retroactively de-functionalize superheroes, free them from the burden of mythic, ideological weight and restore to them a potential that in fact was not necessarily ever fully realized before: their role as wonders and as strange. They will change history by unearthing its strangeness, and this will serve the human race. Planetary then, articulates most clearly the concern of the revisionist comics considered here: superheroes are a liability when they are functionaries, bound to the yoke of social utility. The cold war in particular is responsible for the reduction of the superhero to the role of functionary, as exemplified in Marvel comics of the 1960s, where the heroes were cold warriors constantly combating the red menace. Stan Lee and Jack Kirby's Fantastic Four in particular are representative of this functionalizing: in the original comic they gain their powers through exposure to cosmic rays while trying to beat the U.S.S.R. into space (Lee and Kirby, Fantastic Four\#1) and go on to fight a series of communist villains from behind the Iron Curtain, such as the Red Ghost and his army of super-apes (\#13). Ellis's refiguring of them as the villainous "Four Voyagers" is merely a description of how the Fantastic Four were an ideologically impoverished betrayal of the potentials implicit in the superhero form. Planetary demonstrates that the only option then available is to render heroes functionless, bereft of use, which is merely to restore to them their true functions, which is to be strange and wondrous. In this way they will serve humanity without usurping humanity's place. 
This defunctionalizing is a planetary concern. The image of the entire planet is frequent here, in fact incorporated into the title logo of the book, and the figure of "the world" is employed often, as in fact it is in essentially all the comics considered so far. The planet is an image of totality, but of totality refigured here not as an absolute, or a totalitarian horizon of closure. Totality is presented in its essence as multiplicity, as the multiverse (one universe for every atom of the planet) which is the possibility and presence of the strange that breaks humans from the ideological, liberates humanity, for example, from the mythic thinking of cold war politics that has impoverished reality. "Planetary consciousness," as Alan Moore calls it in his introduction to the first Planetary collection, is the outside of ideological consciousness. It is not a position of total coherence but a position of totality that is only present as incoherent strangeness for the mind. Ellis thus demonstrates the contemporary function of the superhero to be to emancipate the superhero from functionality. Yet the Janus-face of this contemporary function of the superhero emerges when one grasps that for Ellis these seemingly opposed functions, of those who suppress the wonderful and those whocelebrate the strange, are in fact an identity. This identity emerges in the story called "Terra Occulta." This story presents an alternate reality in which the role of the Four Voyagers is played by the Planetary heroes themselves. Here, it is Planetary who have harvested superheroes and functionalized them: the world has been revolutionized by a great technological leap, which is the result of reverse-engineering alien technology and performing autopsies on superhumans in order to create genetic plug-ins for humans. The three figures who should have become Superman, Batman and Wonder Woman track down the masterminds of Planetary and kill them, effectively taking back their world.

It is a peculiar narrative, in which characters portrayed as unequivocally heroic by Ellis in some worlds become, for no apparent reason, the very thing they are fighting against in another. Thus there are no more "villains" here, just superheroes in conflict with each other. The inevitable conclusion to be drawn is that superheroes are both the problem and the solution for humanity. They are as unavoidable as they are untenable. Ellis performs the same gesture in "Ruling the World," in which the Planetary heroes observe another of Ellis's creations, the heroes known as The Authority, coming in conflict with villains from an alternate reality. These villains are simply monstrous versions of The Authority themselves, and Planetary conclude that it demonstrates what the Authority could become: monstrous creatures bent on ruling the world. Planetary can resist this by, as always, keeping the world strange.

Thus the ideological and the strange or historical are not opposites but two sides of a coin, or two separate moments in a single narrative process or substance. Ellis's The Authority is a book dominated by the ambiguous role of the superhero today, creating interpretive confusion and incoherence for readers due to attempts to read the book literally. It serves, perhaps, as the final word on superheroes. Ellis created the title as a spin-off from a more conventional superhero book. In The Authority, in contrast, the heroes begin by explicitly rejecting their traditional roles as crime-fighters, realizing that this is merely an ideological social function that maintains the status quo. It does not save, change or improve the world in any way, and saving and changing the world becomes their mandate. The Authority is yet 
another narrative that seems to ask, what would superheroes do if they were real? Read literally, the book answers that they would make themselves authorities answering to no one, policing the earth, and changing it for what they conceive to be the better. They would do the human race's thinking for it. With issue \#13, when Mark Millar took over the writing of The Authority, this is unquestionably what the book became: comically violent, sex- and drug-filled stories about "realistic" superheroes who answer to no authority but themselves, who travel the Earth unseating oppressive regimes and interfering in human affairs. They are irresponsible social engineers who slaughter cold war Marvel superheroes by the dozens. Yet I think Mark Millar fundamentally misinterpreted The Authority because he read it literally. Consider though that the three villains that Warren Ellis's Authority fight over twelve issues are plainly escapist: an absurd Fu Manchu-like terrorist from a hidden island who simply enjoys terrorizing humanity and has no discernible political agenda, an alien fascist from an alternate Earth who wants to use the human race as a breeding ground with which to repopulate his species, and finally God, in the form of a giant pyramid, who returns to Earth after a long absence and finds it overrun with "insects" to be exterminated. If the reader considers the lack of realism in this supposedly "realistic" superhero narrative a clearer understanding of the allegory of The Authority emerges.

The "villains" they fight are not "realistic," and thus the reader must wonder what exactly the Authority do to really change or save the world, as they repeatedly insist they want to do. The culmination of Ellis's narrative transforms The Authority into an allegory. They kill God, the ultimate villain and enemy of the human race, the metaphysical itself. This story arc, entitled "Outer Dark," begins with an image of the Earth and the words "We are not free" (The Authority: Under New Management \#9). These words must be interpreted: humans are not free as long as they are not the full owners of the Earth. Thus The Authority is an exploration of the problem of reification, secularization, and finally humanization of the world itself. In The Authority, saving the world and changing the world "for the better" as it is generically described are essentially collapsed or conflated into the same activity. Saving the world and changing the world leads to the necessity of unseating and killing God, moreover of reclaiming the world from God. The problem of the "realistic" superhero comic is really the problem of the more "realistic" world, the more human world, the reified, modern world where all metaphysical alibis, all traditional thinking and all maintenance of the status quo, are gradually dissolved, broken up, and bereft of authority. The only remaining authority is the authority of the human itself. The Authority represent this secularized authority, humanity answerable only to itself, and the narrative raises the question: where does reification end? The answer: with the death of god.

Yet this solution is not presented as a solution, at least in Ellis's conclusion. The death of god is also, significantly, the death of the Authority's leader, Jenny Sparks, mutually exclusive positions at once, the position of the human and the position of god. This task is impossible for the mind because the mind does not yet have categories of consciousness outside of the logical opposition of the metaphysical and the material. Yet the process of thought can conceive of such an impossible 
position, if only as an impossible position, and this itself is a kind of utopian promise. The function of the superhero, then, at its very best, is to simply occupy the position of a problem for the mind, a troubling, unanswerable question found in a figure which vacillates uncertainly between human and inhuman, between human and metahuman, which claims to serve humanity while dehumanizing humanity through that service. The function of the superhero today can only finally be to embody impossibility, and thus to give readers a fractional glimpse of the promise of humanity as its own History.

\section{Notes}

${ }^{1}$ See my essay, "The Tides of History: Alan Moore's Historiographic Vision," forthcoming in the on-line journal ImageTexT: Interdisciplinary Comics Studies, for a discussion of Moore and Gibbons' Watchmen.

\section{Works Cited}

Busiek, Kurt and Alex Ross. Marvels. 1994. New York: Marvel Comics, 2001. Ellis, Warren, and John Cassaday. Planetary: All Over the World and Other Stories. 1998-1999. La Jolla, CA: Wildstorm Productions, 2000.

-, and John Cassaday. Planetary: The Fourth Man. 2000-2001. La Jolla, CA: Wildstorm Productions, 2001.

_, Bryan Hitch, Paul Neary and Laura Depuy. The Authority: Relentless. 1999. La Jolla, CA: Wildstorm Productions, 2000.

-, Bryan Hitch, Mark Millar and Frank Quitely. The Authority: Under New Management. 2000. La Jolla, CA: Wildstorm Productions, 2000.

—, Phil Jimenez, Andy Lanning and Laura Depuy. Planetary/The Authority: Ruling the World. La Jolla, CA: Wildstorm Productions, 2000.

-. Jerry Ordway and David Baron. Planetary/JLA: Terra Occulta. La Jolla, CA: Wildstorm Productions, 2002.

Klock, Geoff. How To Read Superhero Comics and Why. New York: Continuum, 2002.

Lee, Stan, and Jack Kirby. Essential Fantastic Four. Vol. 1. 1961-1964. New York: Marvel Comics, 2001.

Lukács, Georg. History and Class Consciousness: Studies in Marxist Dialectics. 1922. Trans. Rodney Livingstone. Cambridge, Mass.: MIT, 1983.

Miller, Frank. "Batman and the Twilight of the Idols: An Interview with Frank Miller." By Christopher Sharrett. The Many Lives of the Batman. Ed. Roberta E. Pearson and William Uricchio. New York, Routledge, 1991.

—, Klaus Janson and Lynn Varley. The Dark Knight Returns. New York: DC Comics, 1986.

Moore, Alan. Introduction. Hellboy: Wake the Devil, by Mike Mignola. Milwaukee, OR: Dark Horse, 1997.

—. "Planetary Conciousness." Introduction. Planetary: All Over the World and 
Other Stories, by Warren Ellis and John Cassaday. 1998-1999. La Jolla, CA: Wildstorm Productions, 2000.

—, Joe Bennett, Chris Sprouse, Rick Veitch and Alex Ross. Supreme: The Return. 1997-2000. Centreville, OH: Checker Book Publishing Group, 2003.

—, Joe Bennett, Rick Veitch and Alex Ross. Supreme: The Story of the Year. 19961997. Centreville, OH: Checker Book Publishing Group, 2002.

—, and Dave Gibbons. Watchmen. 1986-87. New York: DC Comics, 1987.

—, Rob Liefeld and Gil Kane. Judgment Day. 1997-1998. Miamisburg, OH: Checker Book Publishing Group, 2003. 